\title{
The Study of Mechanical Properties of High Strength Concrete Containing Steel and Polypropylene Fibers
}

\author{
Hamid Gholizadeh ${ }^{\text {a*}}$, Samad Dilmaghani ${ }^{\mathrm{a}}$ \\ ${ }^{a}$ Department of Civil Engineering, Tabriz Branch, Islamic Azad University, Tabriz, Iran.
}

Received 06 August 2017; Accepted 27 January 2018

\begin{abstract}
From industrial point of view, recently a great attention has been paid to the use of additives such as steel and polypropylene fibers in concrete and cement products. Investigations have revealed that the addition of steel and polypropylene fibers into normal concrete impart significant improvement in controlling its surface cracking, increase their tensile and flexural strength and durability. Considering the advantages of these additives, high strength concrete samples were produced with different mix design as well as using cement replacement materials such as silica fume according to a well-established experimental set up. The tests show that mixed use of steel and polypropylene fibers give good results in terms of improving structural characteristics of the concrete material developed. In all samples, the surface cracking was decreased significantly by adding suitable fibers in terms of sort, diameter, and length. However, the use of $1 \mathrm{~kg}$ polypropylene and $78 \mathrm{~kg}$ steel fibers in 1 cubic meter concrete was proposed as optimum mix design, regarding the improvement of compressive, tensile and flexural strength of concrete as well as scientific and practical points of view. So that, these newly developed structural concrete reveals promising potentials for further research and development as well as an structurally important building block material.
\end{abstract}

Keywords: High-Strength Concrete; Polypropylene Fibers; Steel Fibers; Silica Fume; Super Plasticizer.

\section{Introduction}

Nowadays, concrete is by far the most widely used construction material. It is versatile, has desirable engineering properties, and also can be molded into any desired shapes and more importantly is produced with very cost-effective raw starting materials. To make good concrete with desired properties, now variety of innovative materials such as fibers, admixtures and construction chemicals, pozzolans and different concrete making techniques are well scientifically adopted in present day modern construction. In recent years, intensive research has resulted in significant advances and innovation in the technology of reinforcement fibers such as glass, polypropylene, carbon, steel etc., and more basic knowledge has been gained on the behavior of cement concrete containing these fibers. Concrete containing hydraulic cement, water, aggregate, and discontinuous discrete fibers is called fiber-reinforced concrete (FRC). The incorporation of short discrete fibers (steel, polypropylene, glass, carbon) can lead to practically useful improvements in the mechanical behavior of a given concrete mixture. In recent years, many studies have been conducted in the mechanical characteristics of FRC. Such FRC is also used in retrofitting and repairing the covering of concrete structure, tunnels, etc. Polypropylene fibers (at relatively low volume fractions of about $<0.3 \%$ ) are used for: secondary temperature shrinkage reinforcement, overlays and pavements, slabs, flooring systems, crash barriers, precast pile shells and shot-crete for tunnel linings, canals and reservoirs [1]. According to the researches, the increase of formability and bending strength are the extra advantages of adding the fibers to the concrete. Two kinds of fiber that very often used in the concrete are: steel fiber and polypropylene fiber [2]. The evaporation of concrete surface

* Corresponding author: hamidgholizadeh2010@gmail.com

\section{doi) http://dx.doi.org/10.28991/cej-030981}

$>$ This is an open access article under the CC-BY license (https://creativecommons.org/licenses/by/4.0/).

(C) Authors retain all copyrights. 
water is a factor in creating the contract paste fracture in concrete which leads to the formation of tension compression since the concrete starts to strengthen [3]. It was mentioned that using polypropylene fibers can improve spalling behavior of concrete [4]. The paste fractures are formed when the acceleration of water evaporation is more than the movement of concrete emulsion to the surface. Here, the negative pressure is generated in the capillaries through which the concrete paste flows and proportionately the tension compression is formed. Such compression is developed during the concrete strengthening and the concrete is cracked where the compression is more than the concrete strength. The cracks caused by paste contracting in the concrete are formed in the first hours after pouring the concrete in the frames and before the concrete reaches its initial strength. Such cracks create critical points in the concrete sensitivity for attaching harmful materials to internal parts of concrete that finally can lead to corrosion and damaging the material in the concrete. Consequently, the performance, servicing or profiting capability, duration, aestheticism and strength of the concrete structures are reduced. Controlling the paste contract tracks in the concrete is of great importance in more duration and resistibility of concrete in the shortest time of structural utilization [4]. In ordinary concrete, where vibration is necessary, the best and most acceptable method for preventing cracks formations caused by paste contract is by using fibers, particularly thin artificial ones with the volume of less than $0.5 \%$ [5, 6]. Polypropylene fibers have hydrophobic levels, which protect them against wetting with cement paste. The hydrophobic nature of polypropylene has no effect on the amount of water needed for concrete. The characteristics of different fibers are listed in the Table 1 [7]. Some techniques that are widely used for high strength concrete development include utilization of natural lightweight aggregates such as pumice, diatomite, and volcanic cinders, or artificial byproducts such as perlite, expanded shale, clay, slate, and sintered pulverized fuel ash (PFA). In spite of its benefits, lightweight concrete exhibits its brittle characteristics and lower tensile strength compared with normal concrete. On the other hand, fiber addition into concrete mixes becomes more widely used to improve concrete tensile behavior. The geometrical size and modulus of elasticity of fibers are the main factors which will affect the performances of fiber reinforced concrete. In order to optimize the benefits of fiber addition in concrete construction, the application of different fiber types into fresh concrete mixtures was introduced and commonly known as hybrid fiber reinforced concrete (HyFRC). It becomes more popular in these recent years and expected to provide better physical and mechanical properties in concrete for structural purposes. The use of different types of fiber in a suitable combination may potentially improve the mechanical properties of concrete and result in synergic performance [8-12]. Addition of steel fiber generally provides contribution to the energy absorbing mechanism (bridging action), while nonmetallic fibers offer its ability to delay the formation of microcracks and avoid catastrophic breaking, and also has much lower density $[11,13]$. In this study the influence of different amount of polypropylene and steel fibers content on concrete properties were investigated by measuring compressive, bending, and splitting tensile strength.

\section{Experimental}

\subsection{Martials}

Cement used for preparation of concrete samples in this study was Portland (type II) cement supplied by Soufian Cement Co. (East Azerbaijan, Iran). Cement used in all studies was of 425-2 type with special density of 3.15 g.cm-3 and Blin area of $3345 \mathrm{~cm} 2 . \mathrm{g}-1$. Chemical composition and physical as well as mechanical characteristics of this cement as reported by the manufacturer were in accordance with Iran National Standard No.398 and Chapter 5 of National Building and Construction Standard.

Table 1. Chemical Analysis of type II Cement

\begin{tabular}{cccccccc}
\hline Oxides & $\mathrm{SiO}_{2}$ & $\mathrm{Al}_{2} \mathrm{O}_{3}$ & $\mathrm{Fe}_{2} \mathrm{O}_{3}$ & $\mathrm{CaO}$ & $\mathrm{MgO}$ & $\mathrm{SO}_{3}$ & Alkaline \\
\hline Percent & $17-25$ & $3-8$ & $0.5-6$ & $60-67$ & $1-4$ & $1-3$ & $0.2-1.3$ \\
\hline
\end{tabular}

In this study, due to the fact that three different assays of cement were used, and also for characterization of concrete resistance conditions for assays higher than $600 \mathrm{~kg} / \mathrm{m}^{3}$, cement assays from 480 to $600 \mathrm{~kg} / \mathrm{m}^{3}$ were adopted. Water used in concrete samples mix design was Tabriz City potable water which is accordance with National Construction Requirements [14]. Sand used was of river sand type supplied by Misho Sand Company (Marand, East Azerbaijan). Trial and error approach was adopted in order to obtain an optimum mixing ratio of gravels to achieve a rather ideal composition. A typical example of the mentioned approach is as follows; $21 \%$ with $50 \%$ sand having $70 \%$ of its particles in 0-3 mm range and 30\% in 3-6 mm range. Special density of mixed sand was measured to be 2.51 g. $\mathrm{cm}^{-3}$ and its water uptake was $0.92 \%$. In order to minimize the experimental errors and obtaining consistent as well as logical results, water uptake, moisture and special weight of the sand in SSD state before sampling were measured and the results were indicated in Table 2. 
Table 2. Characteristics of Sand used for concrete samples preparation

\begin{tabular}{cccccc}
\hline No. & Property/Details of Test & Unit & Standard & Standard Limit & Test Result \\
\hline 1 & Grain Distribution & - & ASTM C136 & - & Appendix \\
2 & $\begin{array}{c}\text { Sand Softness Index } \\
\text { Transferred from 200 } \\
\text { sieve } \\
3\end{array}$ & - & ASTM C136 & $2.3-3.2$ & 3.14 \\
4 & Water uptake & $\%$ & ASTM D 2419 & $\leq 3$ & 1.3 \\
5 & Special weight & gr/cm & ASTM C128 & -2 & 0.92 \\
6 & $\begin{array}{c}\text { Real Special Weight } \\
\text { Saturated Special } \\
\text { Weight with dry } \\
\text { surface }\end{array}$ & $\mathrm{gr} / \mathrm{cm}^{3}$ & ASTM C128 & - & 2.684 \\
7 & $\mathrm{gr} / \mathrm{cm}^{3}$ & ASTM C128 & - & 2.624 \\
\hline
\end{tabular}

Grain size distribution of sand was determined using standard sieves. Distribution curve was in the range recommended in ASTM C33 Standard [15]. Bulk special density of small sized gravels was 2.69 g.cm ${ }^{-3}$ and its water uptake was $2.57 \%$. Maximum diameter of its grain was about $12.5 \mathrm{~mm}$.

Microsilica is added to concrete in its formation state in order to improve mechanical resistance, increase in compression and durability in freezing cycles and decreasing concrete permeability. Microsilica particles which are about 100 times softer than cement, act as effective filler, filling the residual space between cement in concrete so enhancing concrete durability and lowering its permeability. The technical characteristics of the microsilica powder are $\mathrm{pH}$ (9-10), particle size (0.05-0.15 micron), Particle Shape (spherical), Special weight $\left(200-300 \mathrm{Kg} / \mathrm{m}^{3}\right)$, and special surface area $\left(20.4 \mathrm{~m}^{2} / \mathrm{g}\right)$. Table 3 . indicate the chemical analysis of the microsilica power, respectively.

Table 3. Chemical analysis of the microsilica power

\begin{tabular}{ccccccccc}
\hline Material & $\mathrm{AL}_{2} \mathrm{O}_{3}$ & $\mathrm{CaO}$ & $\mathrm{Na}_{2} \mathrm{O}$ & $\mathrm{K}_{2} \mathrm{O}$ & $\mathrm{Fe}_{2} \mathrm{O}_{3}$ & $\mathrm{SO}_{3}$ & L.o.I & Density \\
\hline Percentage \% & $17-23$ & $8-15$ & $>0.9$ & $>0.9$ & $10-12$ & 1.3 & $2-3$ & $1.8-2.1$ \\
\hline
\end{tabular}

Microsilica is usually added at about 5 to $15 \%$ of cement weight at concrete preparation step to the truck mixture followed by same minutes mixing to obtain a homogenous mixture. Also it would enhance total performance efficiency [16]. Noting similar properties of microsilica and microsilica gel and due to lack of microsilica treatment equipment in the laboratory, in this research use was made of only microsilica gel. Microsilica gel was supplied by Forsroc Co. (UK); and its chemical composition $\left(0.4-2 \% \mathrm{Fe}_{2} \mathrm{O}_{3}, 2-2.3 \% \mathrm{CaO}, 0.1-0.9 \% \mathrm{MgO}, 1.7 \% \mathrm{AL}_{2} \mathrm{O}_{3}, 85-95\right.$ $\% \mathrm{SiO} 2$ ) and physical properties were (amorphous structure, spherical shape, 0.2-0.3 Micron grain size distribution, high reaction surface area for hydration reaction, $200 \mathrm{Kg} / \mathrm{m}^{3}$ bulk density) respectively.

In this research, superplasticizing agent Conplast Sp 430 supplied by Iran Fars Co (Ltd.), manufacturing branch of Forsroc, International was used. This compound is a water soluble polycarboxylic acid. According to the instruction provided by the manufacture, $50 \%$ to $2 \%$ of the cement weight can be compromised of this super plasticizing agent, optimum concentration of the agent being 50 to $25 \%$ water solutions. The technical properties of this agent were shown in Table 4.

Table 4. Conplast Sp 430 Technical properties

\begin{tabular}{cc}
\hline State & Concentrated Liquid \\
\hline Color & Brown \\
$\mathrm{pH}$ & 5.6 \\
$\mathrm{ClContent}$ & $\mathrm{No} \mathrm{Cl}$ \\
Density & $1.8 \mathrm{~g} / \mathrm{cm}^{3}$ \\
Package & 1 Barrels and $20 \mathrm{Kg}$ Packs 210 \\
Transport & Non-Dangerous \\
\hline
\end{tabular}

Fibers used for the preparations of samples were steel hooked end and sinusoidal hooked-end provided by Zanjan Wire Co. (Iran). These fibers met the requirements of ASTM 820 Standard. The Characteristics of these fibers were (0.8 $\mathrm{mm}$ fiber diameter, $51 \mathrm{~mm}$ fiber length, 63.75 length/diameter ratio, $7850 \mathrm{Kg} / \mathrm{m}^{3}$ density, and $1220 \mathrm{MPa}$ tensile strength) [17].

In order to prevent problems such as cracking and crack propagation, polypropylene fibers are usually added to the concrete mixture. Also propylene fibers decrease the brittleness of the concrete samples and enhance their fire 
resistance properties. These fibers melt at $160{ }^{\circ} \mathrm{C}$ forming a network of channels through the concrete through which liquids and water vapor cans easily scape thus reducing the internal pressure (Yao 2000). In this work, polypropylene fibers provided by Forsoc Co. (UK) were used. Table 5. indicates the properties of these fibers.

Table 5. Properties of polypropylene fibers

\begin{tabular}{cc}
\hline Material & Polypropylene \\
\hline Kind & staple \\
Water Uptake & 0 \\
Length & $6,12 \mathrm{~mm}$ \\
Diameter & $22 \mathrm{Micron}$ \\
Shape & Fiber \\
Density & $0.91 \mathrm{~g} / \mathrm{cm}^{3}$ \\
Alkaline & 0 \\
Sulfate Content & 0 \\
Chloride Content & 0 \\
Fiber Thickness & $18-30 \mathrm{Micron}$ \\
Young Modulus & $5500-7000 \mathrm{MPa}$ \\
Tensile Strength & $350 \mathrm{~N} / \mathrm{mm}^{2}$ \\
Melting Point & $160^{\circ} \mathrm{C}$ \\
\hline
\end{tabular}

In this work, total amount of microsilica gel and 1/3 of the total water to be used in Mix Design and whole of superplasticizing agent were thoroughly mixed with each other to form a gel with the hope of achieving more enhancing effect of this pozzolan on the concrete properties.

\subsection{Mixing Order}

In Mix Designs of A1, B1, and C1, cement was always added at the final stage because of its different water uptake properties compared with gravels; so if cement was added at the first stage, conglomeration of the mixture is possible. But in Mix Designs of A2-A6 and B2-B6 and C2-C3; cement was added to the mixture one step before final addition. Mixing time after addition of cement for all Mix Designs was about 3-8 min and finally, steel fibers or polypropylene fibers were simultaneously added to the mixture followed by another 3-6 min mixing time.

\subsection{Molding}

In this step, prepared concrete mixtures were molded in cubic $10 \times 10 \times 10 \mathrm{~cm}$ molds that were formerly cleaned and lubricated. After molding, the weight of the samples measured and recorded. Samples were exposed to laboratory environment for $24 \mathrm{~h}$. Then samples were taken out from molds and 3 of the samples were submerged in water for 7 days and another 3 of were submerged for 28 days to be quite treated. After then, samples were taken out form water followed by weighing and measuring their compression resistance. Figure 1. shows the samples after molding step.

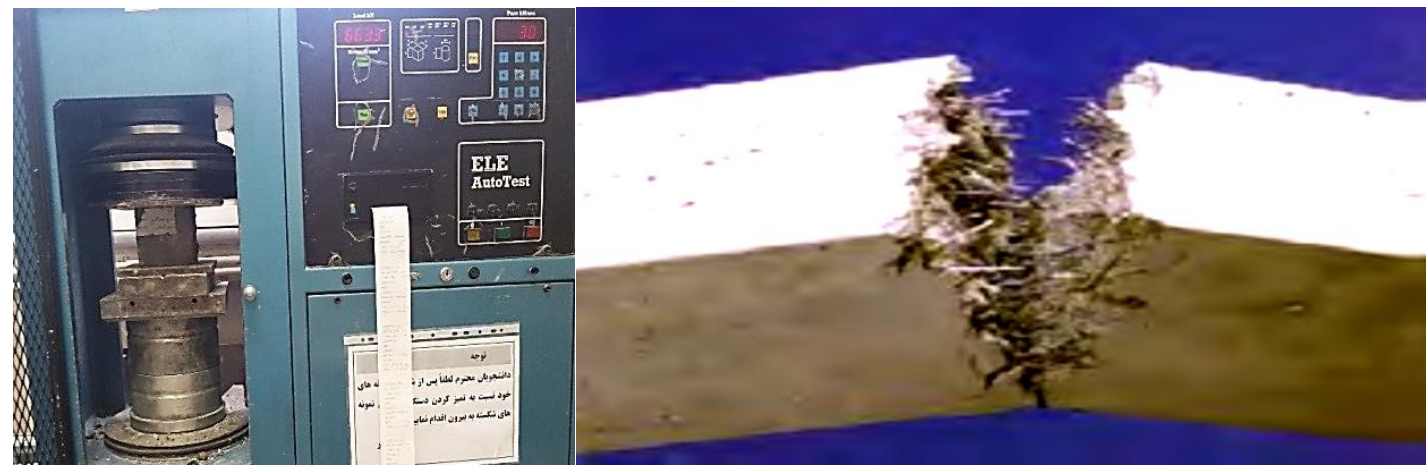

Figure 1. Samples after molding step

\subsection{Mix Design}

The purpose of Mix Design is to develop a formula according to given properties of the concrete. In this work, a total number of $24 \mathrm{Mix}$ Designs was developed in which ratio of water to sticky materials is 0.3, microsilica amount was in three assays of 0,11 and 25 percent of cement weight while super fluiding agent was $3 \%$ sum of weights of cement and microsilica, which this sum is fixed in all Mix Designs. Cement assay was in the range of $480 \mathrm{~kg} / \mathrm{cm}^{3}$ to $600 \mathrm{~kg} / \mathrm{cm}^{3}$. The details of volumetric percentage of rock materials in Mix Design are (1 design code, 21\% nut shaped gravel, $29 \%$ pea shaped gravel, and $50 \%$ sand) 
It should be noted that all parameters in Mix Designs were chosen so that the requirements of ASTMC330 is met as close as possible from grain size distribution point of view. Details of weight percentage of materials for Mix Designs of $\mathrm{A}, \mathrm{B}$, and $\mathrm{C}$ were given in Tables 6 to 8, respectively.

Table 6. Weight percentage of materials for Mix Design of A

\begin{tabular}{ccccccccc}
\hline Mix Design & A1 & A2 & A3 & A4 & A5 & A6 & A7 & A8 \\
\hline $\begin{array}{c}\text { Steel Fibers } \\
\mathrm{kg} / \mathrm{m}^{3}\end{array}$ & 0.0 & 39 & 78 & 117 & 156 & 78 & 0.0 & 0.0 \\
\hline $\begin{array}{c}\text { Polypropylene } \\
\mathrm{kg} / \mathrm{m}^{3}\end{array}$ & 0.0 & 0.0 & 0.0 & 0.0 & 0.0 & 1.0 & 1.0 & 2.0 \\
\hline
\end{tabular}

* Conditions: cement weight $\left(600 \mathrm{~kg} / \mathrm{m}^{3}\right)$, water/bulk ratio $(0.3 \mathrm{~W} / \mathrm{b})$, micro silica $\left(0 \mathrm{~kg} / \mathrm{m}^{3}\right)$, super plasticizer $3.0 \%\left(18.00 \mathrm{~L} / \mathrm{m}^{3}\right)$, nut gravel $(335$ $\left.\mathrm{kg} / \mathrm{m}^{3}\right)$, pea gravel $\left(470 \mathrm{~kg} / \mathrm{m}^{3}\right)$, sand $\left(800 \mathrm{~kg} / \mathrm{m}^{3}\right.$, and water $\left(180 \mathrm{~L} / \mathrm{m}^{3}\right)$.

Table 7. Weight percentage of materials for Mix Design of $B$

\begin{tabular}{cccccccc}
\hline Mix Design & B1 & B2 & B3 & B4 & B5 & B6 & B7 \\
\hline $\begin{array}{c}\text { Steel Fibers } \\
\mathrm{kg} / \mathrm{m}^{3}\end{array}$ & 0.0 & 39 & 78 & 117 & 156 & 78 & 0.0 \\
\hline $\begin{array}{c}\text { Polypropylene } \\
\mathrm{kg} / \mathrm{m}^{3}\end{array}$ & 0.0 & 0.0 & 0.0 & 0.0 & 0.0 & 1.0 & 1.0 \\
\hline
\end{tabular}

* Conditions: cement weight $\left(540 \mathrm{~kg} / \mathrm{m}^{3}\right)$, water/bulk ratio $(0.3 \mathrm{~W} / \mathrm{b})$, micro silica $\left(60 \mathrm{~kg} / \mathrm{m}^{3}\right)$, super plasticizer $3.0 \%\left(18.00 \mathrm{~L} / \mathrm{m}^{3}\right)$, nut gravel $(335$ $\left.\mathrm{kg} / \mathrm{m}^{3}\right)$, pea gravel $\left(470 \mathrm{~kg} / \mathrm{m}^{3}\right)$, sand $\left(800 \mathrm{~kg} / \mathrm{m}^{3}\right.$, and water $\left(180 \mathrm{~L} / \mathrm{m}^{3}\right)$.

Table 8. Weight percentage of materials for Mix Design of $\mathrm{C}$

\begin{tabular}{|c|c|c|c|c|c|c|c|c|}
\hline Mix Design & C1 & $\mathrm{C2}$ & C3 & $\mathrm{C} 4$ & C5 & C6 & C7 & C8 \\
\hline
\end{tabular}

* Conditions: cement weight $\left(480 \mathrm{~kg} / \mathrm{m}^{3}\right)$, water $/$ bulk ratio $(0.3 \mathrm{~W} / \mathrm{b})$, micro silica $\left(120 \mathrm{~kg} / \mathrm{m}^{3}\right)$, super plasticizer $3.0 \%\left(18.00 \mathrm{~L} / \mathrm{m}^{3}\right)$, nut gravel $(335$ $\left.\mathrm{kg} / \mathrm{m}^{3}\right)$, pea gravel $\left(470 \mathrm{~kg} / \mathrm{m}^{3}\right)$, sand $\left(800 \mathrm{~kg} / \mathrm{m}^{3}\right.$, and water $\left(180 \mathrm{~L} / \mathrm{m}^{3}\right)$.

\subsection{Adjustment (Correction) of Weight Percentage of Materials for Mix Design}

Due to the fact that calculated Mix Design was based on microsilica gel used throughout this work, so some correction is necessary to be performed. The corrected weights for Mix Designs of A-C were shown in Tables 9-11, respectively. It should be noted that since no microsilica was used in Mix Design A, so there is no change in weight for Mix Designs A.

Table 9. Corrections made in weight of materials for A Mix Design

\begin{tabular}{ccccccccc}
\hline Mix Design & $\mathbf{A 1}$ & $\mathbf{A 2}$ & $\mathbf{A 3}$ & $\mathbf{A 4}$ & $\mathbf{A 5}$ & $\mathbf{A 6}$ & $\mathbf{A 7}$ & $\mathbf{A 8}$ \\
\hline $\begin{array}{c}\text { Steel Fibers } \\
\mathrm{kg} / \mathrm{m}^{3}\end{array}$ & 0.0 & 39 & 78 & 117 & 156 & 78 & 0.0 & 0.0 \\
\hline $\begin{array}{c}\text { Polypropylene } \\
\mathrm{kg} / \mathrm{m}^{3}\end{array}$ & 0.0 & 0.0 & 0.0 & 0.0 & 0.0 & 1.0 & 1.0 & 2.0 \\
\hline
\end{tabular}

* Conditions: cement weight $\left(600 \mathrm{~kg} / \mathrm{m}^{3}\right)$, water/bulk ratio $(0.3 \mathrm{~W} / \mathrm{b})$, micro silica $\left(0 \mathrm{~kg} / \mathrm{m}^{3}\right)$, super plasticizer $3.0 \%\left(18.00 \mathrm{~L} / \mathrm{m}^{3}\right)$, nut gravel $(335$ $\left.\mathrm{kg} / \mathrm{m}^{3}\right)$, pea gravel $\left(470 \mathrm{~kg} / \mathrm{m}^{3}\right)$, sand $\left(800 \mathrm{~kg} / \mathrm{m}^{3}\right.$, and water $\left(180 \mathrm{~L} / \mathrm{m}^{3}\right)$.

Table 10. Corrections made in weight of materials for B Mix Design

\begin{tabular}{ccccccccc}
\hline Mix Design & B1 & B2 & B3 & B4 & B5 & B6 & B7 & B8 \\
\hline $\begin{array}{c}\text { Steel Fibers } \\
\mathrm{kg} / \mathrm{m}^{3}\end{array}$ & 0.0 & 39 & 78 & 117 & 156 & 78 & 0.0 \\
\hline $\begin{array}{c}\text { Polypropylene } \\
\mathrm{kg} / \mathrm{m}^{3}\end{array}$ & 0.0 & 0.0 & 0.0 & 0.0 & 0.0 & 1.0 & 1.0 \\
\hline
\end{tabular}

* Conditions: cement weight $\left(540 \mathrm{~kg} / \mathrm{m}^{3}\right)$, water/bulk ratio $(0.3 \mathrm{~W} / \mathrm{b})$, micro silica $\left(100 \mathrm{~kg} / \mathrm{m}^{3}\right)$, super plasticizer $3.0 \%\left(18.00 \mathrm{~L} / \mathrm{m}^{3}\right)$, nut gravel $(335$ $\left.\mathrm{kg} / \mathrm{m}^{3}\right)$, pea gravel $\left(470 \mathrm{~kg} / \mathrm{m}^{3}\right)$, sand $\left(800 \mathrm{~kg} / \mathrm{m}^{3}\right.$, and water $\left(140 \mathrm{~L} / \mathrm{m}^{3}\right)$. 
Table 11. Corrections made in weight of materials for $\mathrm{C}$ Mix Design

\begin{tabular}{ccccccccc}
\hline Mix Design & C1 & C2 & C3 & C4 & C5 & C6 & C7 & C8 \\
\hline $\begin{array}{c}\text { Steel Fibers } \\
\mathrm{kg} / \mathrm{m}^{3}\end{array}$ & 0.0 & 39 & 78 & 117 & 156 & 78 & 0.0 \\
\hline $\begin{array}{c}\text { Polypropylene } \\
\mathrm{kg} / \mathrm{m}^{3}\end{array}$ & 0.0 & 0.0 & 0.0 & 0.0 & 0.0 & 1.0 & 1.0 & 2.0 \\
\hline
\end{tabular}

* Conditions: cement weight $\left(480 \mathrm{~kg} / \mathrm{m}^{3}\right)$, water/bulk ratio $(0.3 \mathrm{~W} / \mathrm{b})$, micro silica $\left(200 \mathrm{~kg} / \mathrm{m}^{3}\right)$, super plasticizer $3.0 \%\left(18.00 \mathrm{~L} / \mathrm{m}^{3}\right)$, nut gravel $(335$ $\left.\mathrm{kg} / \mathrm{m}^{3}\right)$, pea gravel $\left(470 \mathrm{~kg} / \mathrm{m}^{3}\right)$, sand $\left(800 \mathrm{~kg} / \mathrm{m}^{3}\right.$, and water $\left(100 \mathrm{~L} / \mathrm{m}^{3}\right)$.

\section{Results and Discussion}

After preparation and treatment of samples in laboratory temperature and environmental conditions, tensile strength, compression strength, bending strength and slump measurements were performed on the samples along with measuring their weight at different conditions.

\subsection{Mean Compression Strength of the Mix Design Samples}

Compression strength of the samples at 27 and 28 days age was measured according to ASTMC39 on cubic $10 \times 10 \times 10 \mathrm{~cm}^{3}$ samples and the results were compared with each other and samples without any steel and/or polypropylene fibers. Measurements were performed with electrohydraulic loading machine with capacity of $2000 \mathrm{KN}$ and a loading rate of $0.3 \mathrm{MPa} / \mathrm{sec}^{1}$. Figure 2 . shows the results for samples with different percent of polypropylene for 7 days age.

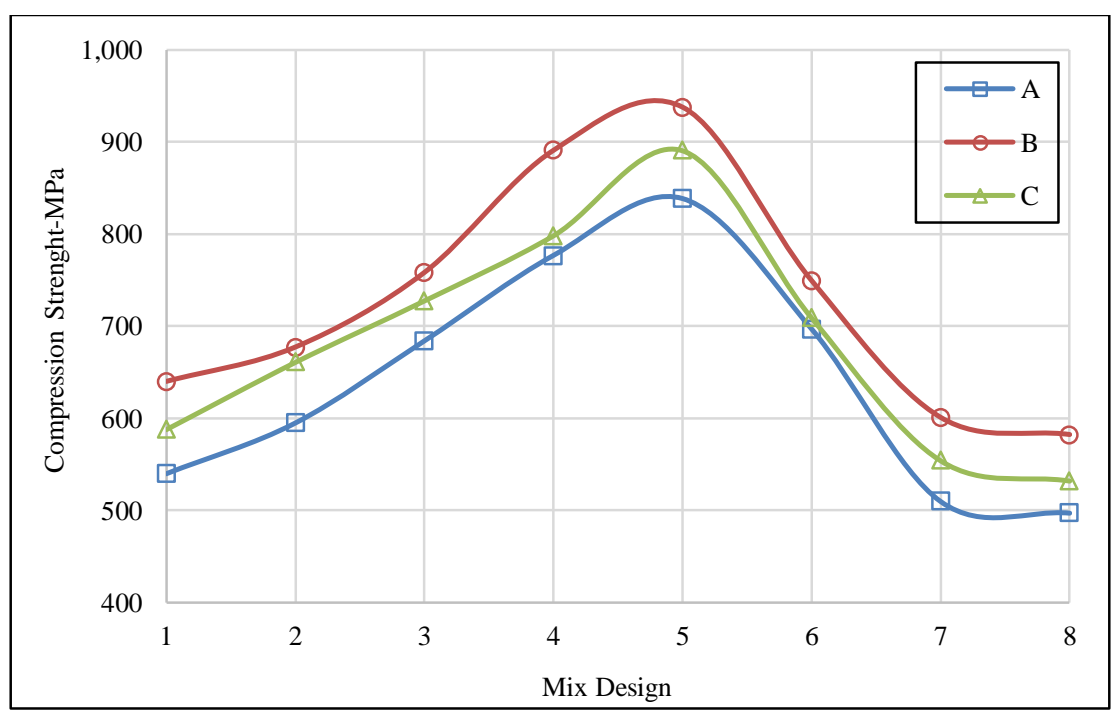

Figure 2. The results for samples with different percent of polypropylene for 7 days age

The similar results for 28 days age samples were given in Figures 3 to 5 .

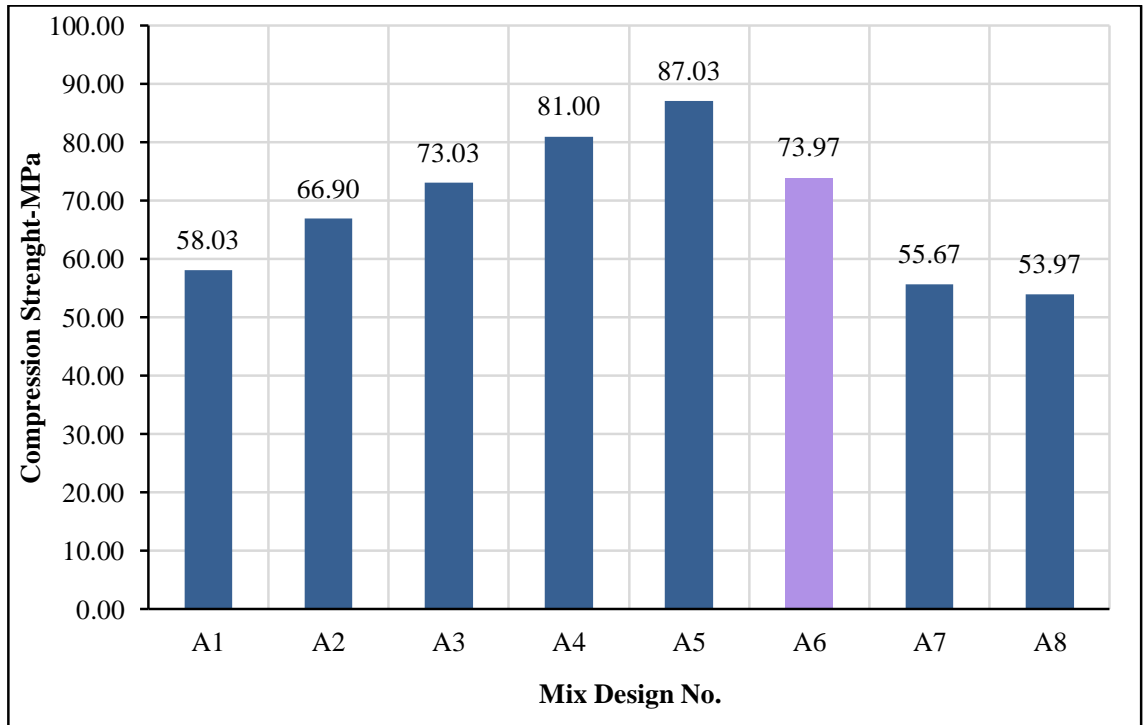

Figure 3. The results for a mix design samples with different percent of polypropylene for 7 days age 


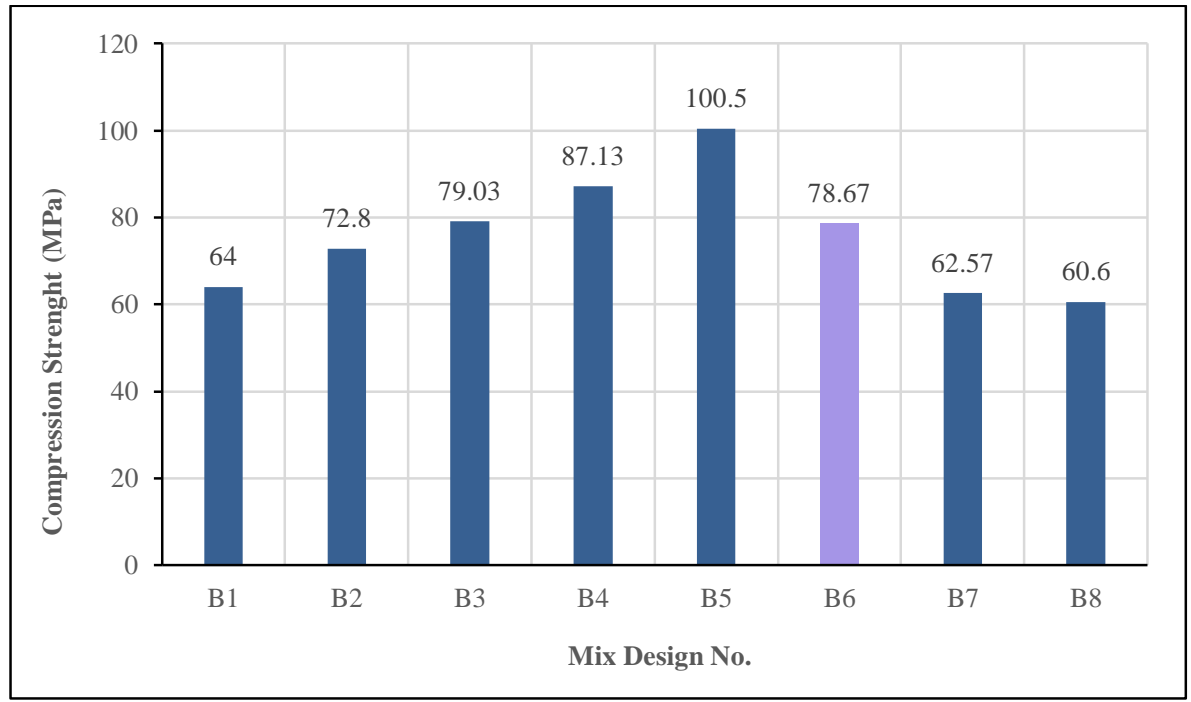

Figure 4. The results for $B$ mix design samples with different percent of polypropylene for $\mathbf{7}$ days age

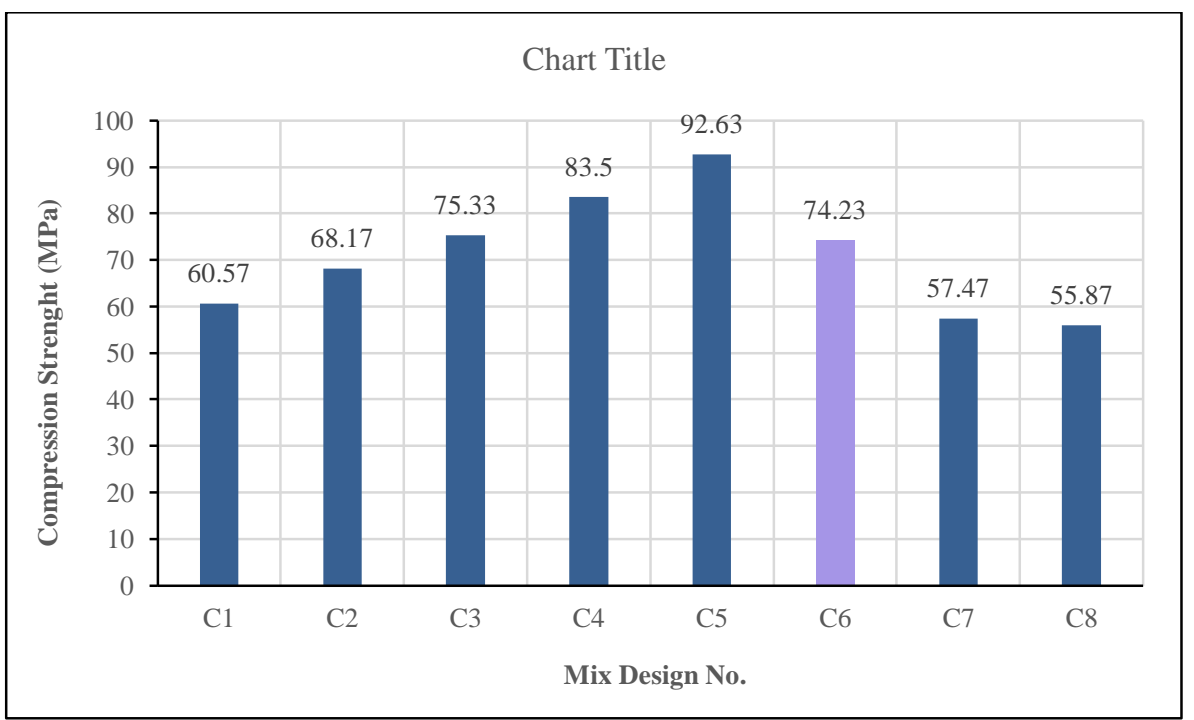

Figure 5. The results for $\mathrm{C}$ mix design samples with different percent of polypropylene for 7 days age

According to the results of Figures 3-5, addition of polypropylene fibers has a negative effect on the compression strength of the concrete samples. This may be attributed to the pores or channels filled with fibers. In other words, addition of polypropylene fibers decreases the compression strength of concrete. Tables 12-14. indicate the same results for samples containing steel fibers after 7 days treatment in water.

Table 12. As above for 7 days age samples containing steel fibers

\begin{tabular}{|c|c|c|c|c|c|c|c|}
\hline \multirow{2}{*}{$\begin{array}{c}\begin{array}{c}\text { Mix } \\
\text { Design }\end{array} \\
\text { A1 }\end{array}$} & \multirow{2}{*}{$\begin{array}{c}\begin{array}{c}\text { Fiber } \\
\text { Content } \\
\mathbf{k g}^{\mathbf{3}} \mathbf{m}^{\mathbf{3}}\end{array} \\
0\end{array}$} & \multirow{2}{*}{$\begin{array}{c}\begin{array}{c}\text { Fiber } \\
\text { Content } \\
(\%)\end{array} \\
0\end{array}$} & \multicolumn{3}{|c|}{$\begin{array}{c}7 \text { days strength of } 3 \text { samples } \\
\text { (Mpa) }\end{array}$} & \multirow{2}{*}{$\begin{array}{c}\begin{array}{c}\text { Mean of } 7 \text { days } \\
\text { Compression } \\
\text { Strength }\end{array} \\
54.00\end{array}$} & \multirow{2}{*}{$\begin{array}{r}\begin{array}{r}\text { Percentage of change in } \\
\text { strength compared with } \\
\text { sample without fiber }(\%)\end{array} \\
0\end{array}$} \\
\hline & & & 56.1 & 53.5 & 52.4 & & \\
\hline A2 & 39 & 0.50 & 57.3 & 59.8 & 61.4 & 59.50 & 10 \\
\hline A3 & 78 & 1.00 & 68.7 & 68.5 & 68.0 & 68.40 & 27 \\
\hline A4 & 117 & 1.50 & 76.5 & 78.5 & 78.0 & 77.67 & 44 \\
\hline A5 & 156 & 2.00 & 83.5 & 83.8 & 84.2 & 83.83 & 55 \\
\hline A6 & 78 & 1.00 & 68.4 & 70.0 & 70.7 & 69.70 & 29 \\
\hline
\end{tabular}

Table 13. As above for 7 days age samples containing steel fibers

\begin{tabular}{|c|c|c|c|c|c|c|c|}
\hline $\begin{array}{c}\text { Mix } \\
\text { Design }\end{array}$ & $\begin{array}{l}\text { Fiber } \\
\text { Content } \\
\mathrm{kg} / \mathrm{m}^{3}\end{array}$ & $\begin{array}{c}\text { Fiber } \\
\text { Content } \\
(\%)\end{array}$ & \multicolumn{3}{|c|}{$\begin{array}{c}7 \text { days strength of } 3 \text { samples } \\
\text { (Мpa) }\end{array}$} & $\begin{array}{l}\text { Mean of } 7 \text { days } \\
\text { Compression } \\
\text { Strength }\end{array}$ & $\begin{array}{l}\text { Percentage of change in } \\
\text { strength compared with } \\
\text { sample without fiber }(\%)\end{array}$ \\
\hline B1 & 0 & 0 & 64.1 & 63.8 & 64.0 & 63.97 & 0 \\
\hline B2 & 39 & 0.50 & 66.5 & 68.0 & 68.6 & 67.70 & 6 \\
\hline B3 & 78 & 1 & 74.1 & 76.0 & 74.7 & 74.93 & 17 \\
\hline
\end{tabular}




\begin{tabular}{cccccccc}
\hline B4 & 117 & 1.50 & 90.8 & 90.4 & 86.0 & 89.07 & 39 \\
B5 & 156 & 2 & 94.1 & 93.2 & 94.0 & 93.77 & 47 \\
B6 & 78 & 1 & 76.1 & 75.9 & 75.4 & 75.80 & \ \\
\hline
\end{tabular}

Table 14. As above for 7 days age samples containing steel fibers

\begin{tabular}{|c|c|c|c|c|c|c|c|}
\hline $\begin{array}{c}\text { Mix } \\
\text { Design }\end{array}$ & $\begin{array}{c}\text { Fiber } \\
\text { Content } \\
\mathrm{kg} / \mathrm{m}^{3}\end{array}$ & $\begin{array}{c}\text { Fiber } \\
\text { Content } \\
(\%)\end{array}$ & $\begin{array}{l}\text { Mean of } 7 \text { days } \\
\text { Compression } \\
\text { Strength }\end{array}$ & \multicolumn{3}{|c|}{$\begin{array}{c}7 \text { days strength of } 3 \text { samples } \\
\text { (Mpa) }\end{array}$} & $\begin{array}{l}\text { Percentage of change in } \\
\text { strength compared with } \\
\text { sample without fiber }(\%)\end{array}$ \\
\hline $\mathrm{C} 1$ & 0 & 0 & 58.80 & 60.3 & 57.1 & 59.0 & 0 \\
\hline $\mathrm{C} 2$ & 39 & 0.50 & 66.10 & 65.8 & 66.4 & 66.1 & 12 \\
\hline $\mathrm{C} 3$ & 78 & 1 & 72.77 & 73.2 & 73.0 & 72.1 & 24 \\
\hline $\mathrm{C} 4$ & 117 & 1.50 & 79.83 & 80.0 & 80.1 & 79.4 & 36 \\
\hline C5 & 156 & 2 & 89.07 & 89.2 & 87.9 & 90.1 & 51 \\
\hline C6 & 78 & 1 & 70.93 & 70.1 & 70.6 & 72.1 & 21 \\
\hline
\end{tabular}

\subsection{Tensile Strength of Samples}

Samples of reinforced concrete (with steel fibers and polypropylene fibers) were tasted by samples cleavage (Brazilian) test. Tensile strength measurements were performed on 28 days age samples according to ASTMC 496 Standard. In this test, cylindrical samples with $100 \times 200 \mathrm{~mm}^{2}$ dimensions were used. Tensile strength was calculated according to the following equation:

$T=\frac{2 P}{\pi L} \times d^{2}$

Where $\mathrm{T}$ is the tensile strength $\left(\mathrm{kg} / \mathrm{cm}^{2}\right), P$ indicated the maximum load applied $(\mathrm{kg}), \mathrm{L}$ is the length of sample $(\mathrm{cm})$ and finally $\mathrm{d}$ shows the diameter of the sample $(\mathrm{cm})$.

\subsection{Bending Strength of Samples}

For this test, pyramid shaped samples with dimensions of $10 \times 10 \times 50 \mathrm{~cm}^{3}$ were used according to AREM Part 4 Guidelines (ASTM C1609/C 2005). Bending strength (Fracture resistance) was calculated by the following equation:

$F r=\frac{M C}{I}=\frac{P L}{b h^{2}}$

Where Fr is the Fracture resistance of concrete $\left(\mathrm{N} / \mathrm{mm}^{2}\right), \mathrm{P}$ is the maximum load applied $(\mathrm{N}), \mathrm{d}$ is the width of sample $(\mathrm{mm})$ and $\mathrm{h}$ indicates the height of the sample $(\mathrm{mm})$.

Generally, increase in bending strength (fracture resistance) is in close relation with an increase in tensile resistance because practically tension developed from bonding is the controlling factor of the Fracture load. Results of this work show that at single point loading additions, steel as well as polypropylene fibers significantly enhances bending strength through improvements in transition zone and micro crack control.

\subsection{Analysis of Compression Strength Results}

In all cases, with increasing polypropylene content in the concrete samples, compression strength decreases due to some voids formed in the concrete matrix by fibers. But with increasing steel fibers, in all cases, compression strength increases up to $1.5 \%$ steel fibers content but beyond this percentage, no significantly enhancing effect was observed.

\subsection{Analysis of Tensile Strength Results}

In all cases, addition of fibers (both of polypropylene and steel fibers) increases the tensile strength but this is not the case with high fibers content more than $2 \mathrm{~kg} / \mathrm{m}^{3}$ at which a sudden decrease in tensile strength is observed. This finding may be attributed to the fact that at low contents, fibers act as proper reinforcing materials but at high content they lower density and increase porosity so, as a result, tensile strength decreases beyond $2 \mathrm{~kg} / \mathrm{m}^{3}$ of fibers content (Figure 6). 


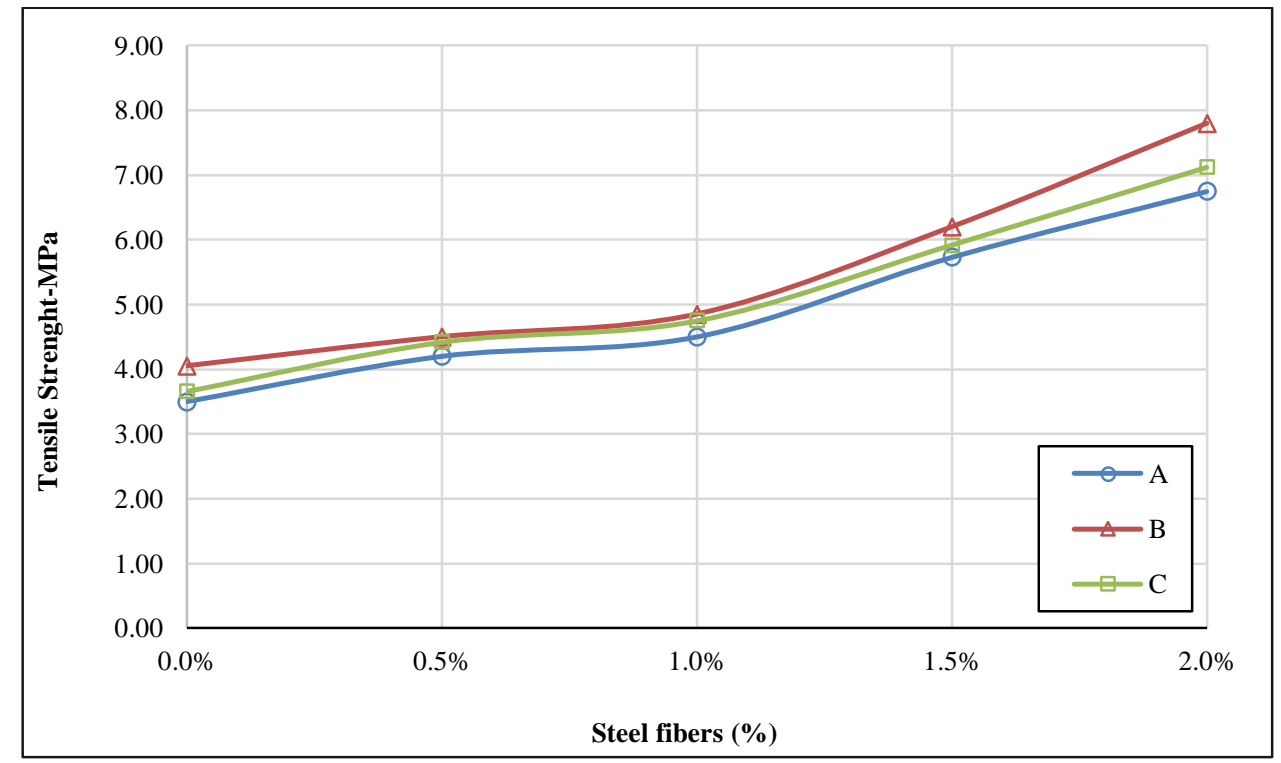

Fihure 6. The effect of steel fibers on the compressive tensile test

\subsection{Analysis of Fracture Resistance (Bonding Strength)}

Addition of steel fibers significantly enhances bending strength of concrete. Low fiber content inserts more profound results. Due to rather higher cost of steel fibers, it is suggested by the results obtained in this study that steel fibers are to be used at a content of about $78 \mathrm{~kg} / \mathrm{m}^{3}$ or about $1 \%$ of concrete content. Tables 12-14. and Figure 7. gives the summery of the results obtained for compression, tensile, and bending strength of samples with different Mix Designs (A, B, and C).

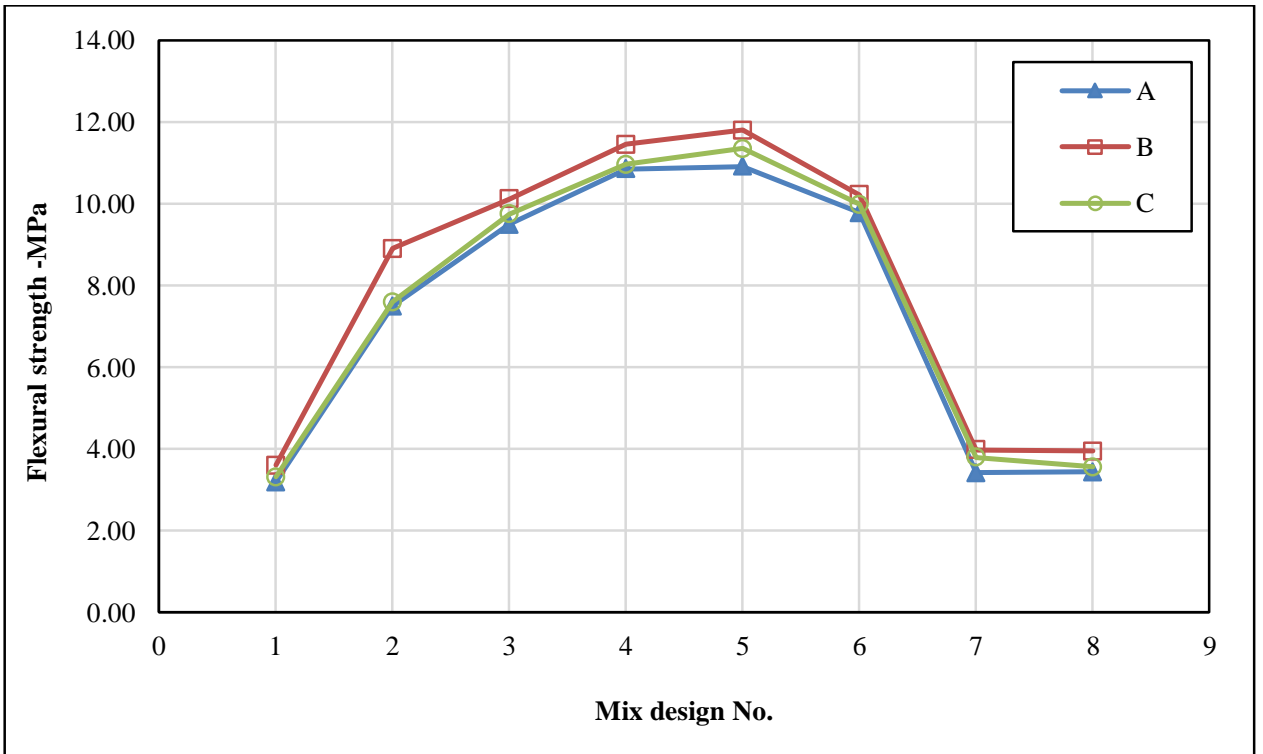

Figure 7. Flexural strength test results

\section{Conclusion}

According to the experimental results detained and further analysis performed, the following conclusions may be asserted from this study:

- Addition of microsilica up to $25 \%$ enhances the compression strength with on optimum content to be about $11 \%$. The same finding is true in the case of both tensile strength and fracture resistance. Additions beyond $25 \%$ has no more significant enhancing effect and further additions may lower concrete strength characteristics due to micro filler effect of microsilica and its incapability to participate in hydration reactions.

- Addition of steel fibers significantly enhances all of three types of strengths i.e. compression, tensile, and bending resistance. This enhancing effect is rather slow up to $1 \%$ of fibers content but beyond this a sharp increase in concrete resistance was observed. 
- Addition of polypropylene to high strength concrete, decrease the compression strength but on the other hand has positive effect on tensile strength up to $2 \mathrm{~kg} / \mathrm{m}^{3}$ fibers content at which increase in tensile strength as doped from $7 \%$ down to $4 \%$. The same is true for bending resistance and at a fiber content of $1 \mathrm{~kg} / \mathrm{m}^{3}$, bending strength increases about $11 \%$ and at fiber content of $2 \mathrm{~kg} / \mathrm{m}^{3}$, enhancing effect was rather less and was about $8 \%$.

- Combining $1 \%$ steel fibers and $1 \mathrm{~kg} / \mathrm{m}^{3}$ polypropylene, has a net enhancing effect on compression strength and also on tensile strength as well as to some to some extent on bending strength.

\section{References}

[1] Zheng, Z., and Feldman, D. "Synthetic fiber-reinforced concrete. Progress in Polymer Science", 20(3): 185- 210, 1995. https://doi.org/10.1016/0079-6700(94)00030-6.

[2] Abrishambaf, A.J., Barros, A., Cunha, V.M.C.F. "Tensile stress-crack width law for steel fiber reinforced self-compacting concrete obtained from indirect (splitting) tensile tests", Cem. Concr. Compos. Volume 57, pages 153-165, 2015. https://doi.org/10.1016/j.cemconcomp.2014.12.010.

[3] Han, C., Hwang, Y., Yang, S., and Gowripalan, N. Performance of spalling resistance of high performance concrete with Polypropylene fiber contents and lateral confinement. Cement and Concrete Research, 2005, 35: 17471753. https://doi.org/10.1016/j.cemconres.2004.11.013.

[4] Zeiml, M., Leithner, D., Lackner, R. and Mang, H. How do Polypropylene fibers improve the spalling behavior of in situ concrete. Cement and Concrete Research, 36: 929-941, 2006. https://doi.org/10.1016/j.cemconres.2005.12.018.

[5] Banthia, N. and Gupta, R. Influence of Polypropylene fiber geometry on plastic shrinkage cracking in concrete. Cement and Concrete Research, 36: 1263-67, 2006. https://doi.org/10.1016/j.cemconres.2006.01.010.

[6] Nagarkar, P., Tambe, S., and Pazare, D. 1987. Study of fiber reinforced concrete.

[7] Won, C., Park, S., Lee, C.J., and Won, C., Effect of crimped synthetic fiber surface treatments on plastic shrinkage cracking of Cement-based composites. Magazine of Concrete Research, 60: 421-42, 2008. https://doi.org/10.1680/macr.2006.00033.

[8] Ahmed, S.F.U., Maalej, M., and Paramasivam, P. Flexural responses of hybrid steel-polyethylene fiber reinforced cement composites containing high volume fly ash. Construction and Building Materials, 21: 1088-1097, 2007. https://doi.org/10.1016/j.conbuildmat.2006.01.002.

[9] Altun, F., Haktanir, T., and Ari, K. 2007. Effects of steel fiber addition on mechanical properties of concrete and RC beams. Construction and Building Materials, 21(3): 654- 661. https://doi.org/10.1016/j.conbuildmat.2005.12.006.

[10] Banthia, N., and Nandakumar, N. Crack growth resistance of hybrid fiber reinforced cement composites. Cement and Concrete Composites, 25(1): 3-9, 2003. https://doi.org/10.1016/s0958-9465(01)00043-9.

[11] Sivakumar, A., and Santhanam, M. 2007. Mechanical properties of high strength concrete reinforced with metallic and nonmetallic fibers. Cement and Concrete Composites, 29(8): 603-608. https://doi.org/10.1016/j.cemconcomp.2007.03.006.

[12] Yermak, N., Pliya, P., Beaucour, A-L., Simon, A., Noumowe, A., "Influence of steel and/or polypropylene fibres on the behaviour of concrete at high temperature: Spalling, transfer and mechanical properties", Construction and Building Materials, Volume 132, pages 240-250, 2017. https://doi.org/10.1016/j.conbuildmat.2016.11.120.

[13] Nguyen, D.L., Ryu, G.S., Koh, K.T., Kim, D.J., Size and geometry dependent tensile behavior of ultra-high-performance fiber-reinforced concrete, Compos, Volume 58, pages 279-292, 2014. https://doi.org/10.1016/j.compositesb.2013.10.072.

[14] Beddar, M., Development of steel fiber reinforced concert from antiquity until the present-day. Proceedings, Int Conference Concrete: Construction sustainable option, Dundee, UK, pp 35-44, 2008. https://doi.org/10.1680/scc.31777.0009.

[15] ASTM C1609/C 1609M-05, Flexural Performance of Fiber-Reinforced Concrete (Using Beam With Third-Point Loading), ASTM International, West Conshohocken, 2005. pp. 8. https://doi.org/10.1520/c1609_c1609m-07.

[16] Tomas, J. and Ramaswamy, A. Mechanical Properties of Steel Fiber-Reinforced Concrete. Journal of materials in Civil Engineering, ASCE, 19(5): 385-392, 2007. https://doi.org/10.1061/(asce)0899-1561(2007)19:5(385).

[17] Oh, Y.H., Evaluation of Flexural Strength for Normal and High Strength Concrete with Hooked Steel Fibers. Journal of the Korea Concrete Institute, 20(4): 531-539, 2008. https://doi.org/10.4334/jkci.2008.20.4.531. 